\title{
SISTEM PAKAR DIAGNOSIS PENYAKIT BUAH ANGGUR MENGGUNAKAN METODE DEMPSTER SHAFER BERBASIS WEB
}

\author{
Muhammad Yusuf Amin, Ali Mahmudi, Nurlaily Vendyansyah \\ Program Studi Teknik Informatika S1, Fakultas Teknologi Industri \\ Institut Teknologi Nasional Malang, Jalan Raya Karanglo km 2 Malang, Indonesia \\ muhammadyusufamin@gmail.com
}

\begin{abstract}
ABSTRAK
Salah satu penyebab rendahnya produksi dan kualitas buah anggur di Desa Sumberbendo, Kecamatan Sumberasih, Kabupaten Probolinggo adalah adanya serangan hama penyakit yang menyerang mulai dari tanaman sampai buahnya sendiri,. Untuk meningkatkan produksi hasil tanaman anggur akibat adanya serangan hama penyakit tanaman, perlu dilakukan langkah-Iangkah yang terkoordinasi di lapangan, khususnya dalam mengantisipasi muncul dan berkembangnya hama penyakit, sesuai rakitan teknologi budidaya anggur yang dianjurkan. Untuk membantu para petani dalam pengelolaan tanaman anggur dalam mendiagnosa penyakit akibat serangan hama, dikembangkan perangkat lunak yang dapat diakses melalui web. Aplikasi yang dikembangkan dalam penelitian ini berbasis pada sistem pakar, dimana segala macam penyakit yang lazim pada tanaman anggur akibat serangan hama dapat didiagnosis dan memberi solusi penanganan layaknya seorang pakar. Sistem pakar pada penelitian kali ini menggunakan metode Dempster shafer. Data yang digunakan pada penelitain kali ini berupa data gejala, data penyakit, dan data solusi pengendalian yang didapatkan dari Balai Tanaman Jeruk dan Subtropika Kota Batu, dan divalidasi oleh pakar ahli dalam bidang tanaman pada instansi tersebut.
\end{abstract}

Kata kunci : Anggur,Sistem Pakar,Dempster Shafer

\section{PENDAHULUAN}

\subsection{Latar Belakang}

Keterbatasan jumlah seorang pakar atau ahli yang dapat menentukan penyakit tanaman anggur dan cara penanggulangannya mengakibatkan produksi buah anggur dapat menurun drastis setiap tahunnya tidak hanya itu, ketidakhadiran seorang pakar dalam mengidentifikasi penyakit mengakibatkan proses penyembuhan terhambat. Selain itu, posisi seorang pakar yang jauh dengan lahan tanaman anggur yang terserang penyakit juga menjadi faktor penghambat penyembuhan tanaman. Untuk menanggulangi halhal tersebut dibangunlah sebuah sistem komputer yang mampu diakses dimana saja dan kapan saja oleh pemilik lahan pertanian atau petani sebagai pengganti peran seorang pakar apabila pakar tersebut tidak hadir.

Sistem pakar adalah sistem berbasis komputer yang menggunakan pengetahuan, fakta, dan teknik penalaran dalam memecahkan masalah yang biasanya hanya dapat dipecahkan oleh pakar bidang tertentu. Sistem pakar dapat digunakan untuk menyimpan pengetahuan dan keahlian pakar. Dengan menggunakan sistem pakar para petani dapat dengan mudah mendiagnosa penyakit yang menyerang tanaman anggur mereka karena sistem pakar dapat digunakan untuk menyimpan pengetahuan dan keahlian pakar, selain itu sistem pakar dapat meningkatkan kapabilitas dalam menyelesaikan masalah sehingga menghemat waktu dalam pengambilan keputusan. Adapun cara kerja dari sebuah sistem pakar adalah user memasukkan faktafakta atau gejala yang dialami ke dalam sebuah sistem pakar, Kemudian fakta-fakta yang telah dimasukan tersebut akan dikirim ke dalam mesin inferensi Mesin inferensi tersebut akan mengolah fakta-fakta tersebut berdasarkan aturan-aturan logika yang ada pada basis pengetahuan yang telah dibuat. Ketika sudah selesai diolah, sistem pakar akan memberikan output atau jawaban yang sudah diolah oleh mesin inferensi berdasarkan pengetahuan yang ada pada sistem pakar. Jawaban tersebut akan tampil di User Interface sistem pakar sendiri. Tentunya sistem pakar ini tidak akan menggantikan peran pakar ahli dari berbagai bidang tetapi hanya sebagai pembantu untuk menganalisis suatu penyakit yang ada buah anggur.

Berdasarkan permasalahan di atas maka dibangun sebuah sistem pakar berbasis web dengan judul "Sistem Pakar Diagnosis Penyakit Buah Anggur Menggunakan Metode Dempster Shafer Berbasis Web "Dengan adanya website ini diharapkan mempermudah para petani untuk mengetahui gejala mendapatkan informasi pengendalian hama/penyakit.

\subsection{Rumusan Masalah}

Berdasarkan permasalahan yang telah dipaparkan di latar belakang, maka masalah dapat dirumuskan sebagai berikut :

1. Bagaimana cara membangun sistem pakar diagnosis penyakit buah anggur?

2. Bagaimana cara membangun sistem pakar penyakit buah anggur di Desa Sumberbendo, Kecamatan Sumberasih, Kabupaten Probolinggo ?

3. Bagaimana cara membangun website? 


\subsection{Batasan Masalah}

Untuk lebih memfokuskan pada permasalahan yang akan diteliti, maka penelitian ini dibatasi sebagai berikut :

1. Data yang digunakan dalam penelitian menggunakan data sekunder yaitu buku Bertanam Anggur oleh Drs. Srijono, B.Sc Penerbit PT BALAI PUSTAKA (Persero) dan Bertanam Anggur Oleh Setiadi Penerbit PENEBAR SWADAYA, kemudian divalidasi oleh ahli pakar pada kantor BALAI PENELITIAN TANAMAN JERUK DAN BUAH SUBTROPIKA, KOTA BATU.

2. Jumlah penyakit yang ada pada buah anggur 13 jenis penyakit dan 28 gejala

3. Menggunakan metode Dempster Shafer dalam penelitian sistem pakar buah Anggur

4. Jumlah user ada 2 yaitu petani dan pakar

5. Bahasa Pemograman yang digunakan adalah HTML, CSS, PHP dan JAVA SCRIPT.

\subsection{Tujuan}

Adapun tujuan yang ingin dicapai dalam penelitian ini adalah

1. Sistem pakar ini menggunakan metode dempster shafer

2. Menghasilkan sistem pakar anggur yg datanya diperoleh Balijestro dan divalidasi oleh pakar ahli

3. Tools yang digunakan untuk membuat web sistem pakar adalah Sublime Text, Xampp

\section{TINJAUAN PUSTAKA}

\subsection{Penelitian Terkait}

Nilai Certainty Factor yang dihasilkan dari metode Certainty Factor dan nilai densitas yang dihasilkan dari metode Dempster-Shafer pada setiap hasil diagnosis yang dihasilkan oleh kedua metode. Hal ini berguna untuk memperkuat keyakinan pengguna akan penyakit yang dialami kelinci. Pada pengujian dengan metode Certainty Factor, didapatkan nilai keakuratan sebesar $80 \%$, sedangkan hasil pengujian dengan metode Dempster-Shafer didapatkan nilai keakuratan sebesar $85 \%$ Perbedaan hasil diagnosis antara kedua metode disebabkan oleh perbedaan mendasar dalam perhitungan keduanya, di mana perhitungan dari setiap kemungkinan penyakit pada metode Certainty Factor tidak saling terkait dan dihitung sendiri-sendiri sedangkan perhitungan dari setiap kemungkinan penyakit pada metode Dempster-Shafer selalu saling terkait. [1].

Berdasarkan hasil pengujian sistem terhadap 25 kasus uji menunjukkan akurasi sebesar 92\%. Hal ini menunjukan bahwa sistem sudah cukup baik dan dapat digunakan untuk mendiagnosis penyakit pada tanaman kedelai. Ketidakakuratan sistem sebesar $8 \%$, dikarenakan perhitungan yang dilakukan menggunakan metode Dempster-shafer yang menggunakan nilai tertinggi tanpa adanya optimasi nilai densitas pada setiap gejala. [2]
Program aplikasi sistem pakar ini dibuat untuk membantu pembudidaya tanaman anggur mengetahui hama dan penyakit yang menyerang tanaman anggur dan dapat menemukan solusi dari penyakit tersebut berdasarkan gejala-gejala yang tampak sehingga dapat melakukan upaya pengobatan dan pencegahannya. Aplikasi ini menggunakan metode certainty factor, dimana nilai CF masing-masing gejala diperoleh dari dari pakar sehingga dapat menunjukan besarnya keyakinan pada tanaman anggur yang terserang penyakit. Nilai keyakinan yang dihasilkan dari sistem ini sama dengan hasil perhitungan manual dengan menggunakan metode certainty factor. Sistem aplikasi ini terdapat fasilitas untuk menangani munculnya pengetahuan baru dan untuk mengubah pengetahuan / basis aturan. [3].

Pemodelan sistem pakar diagnosis penyakit sapi dengan metode Dempster-Shafer merupakan solusi alternatif untuk mengetahui penyakit yang menyerang pada sapi. Sistem yang dibangun mengolah data penyakit sapi berdasarkan data gejala yang diinputkan dan dihitung dengan metode Dempster-Shafer sehingga menghasilkan klarifikasi penyakit pada sapi. Hasil dari pengujian didapatkan nilai akurasi sebesar 75,17\%.. Berdasarkan dari akurasi yang didapat dapat disimpulkan bahwa metode DempsterShafer cukup baik digunakan untuk diagnosa penyakit sapi. [4].

\subsection{Pengertian Sistem Pakar}

Sistem pakar adalah sistem perangkat lunak komputer yang menggunakan ilmu, fakta, dan teknik berpikir dalam pengambilan keputusan untuk menyelesaikan masalah-masalah yang biasanya hanya dapat diselesaikan oleh tenaga ahli dalam bidang yang bersangkutan. Seseorang yang bukan pakar menggunakan sistem pakar untuk meningkatkan kemampuan pemecahan masalah, sedangkan seorang pakar menggunakan sistem pakar untuk knowledge assistantI [5].

Atau secara ringkasnya Sistem pakar (expert system) secara umum adalah sistem yang berusaha mengadopsi pengetahuan manusia ke komputer, agar komputer dapat menyelesaikan masalah seperti yang biasa dilakukan oleh para ahli. Atau dengan kata lain sistem pakar adalah sistem yang didesain dan diimplementasikan dengan bantuan bahasa pemrograman tertentu untuk dapat menyelesaikan masalah seperti yang dilakukan oleh para ahli

Konsep sistem pakar dapat meliputi enam hal berikut :

1. Kepakaran (Expertise)

Kepakaran adalah suatu ilmu yang dapat diperoleh dari pelatihan,membaca buku dan pengalaman dari seseorang. kepakaran inin yang bisa membuat para ahli memungkinkan untuk mengambil suatu keputusan atau kesimpulan yang lebih baik dari yang bukan ahlinya.

2. Pakar (Expert) 
Pakar adalah seseorang yang mempunyai ilmu tentang metode khusus dan mampu untuk menerapkannya untuk memecahkan suatu masalah . pakar disini harus mampu untuk menyelesaikan hal-hal yang berkaitan dengan dengan topik permasalah yang dihadapinya, dan jika perlu ia harus mampu menyusun kembali masalah yang didapatkan, dan dapat memecah aturan serta menentukan relevansi kepakarannya

3. Pemindahan kepakaran (Transfering Expertise)

Tujuan dari sistem pakar adalah memindahkan ilmu kepakaran dari seseorang pakar kemudian ilmu tersebut diterapkan ke dalam computer, kemudian digunakan kepada orang lain yang bukan pakar.

4. Aturan-aturan (Rule)

Saat ini kebanyakan software sistem pakar komersional adalah sistem yang berbasis rule (rule-based system), yaitu pengetahuan disimpan terutama dalam bentuk rule, sebagai prosedur-prosedur pemecahan masalah.

5. Kemapuan menjelaskan (Explanation Capability)

Penjelasan dilakukannya dalam subsistem yang disebut subsistem penjelasan (explanation). Bagian dari sistem ini memungkinkan sistem untuk memeriksa penalaran yang dibuatnya sendiri dan menjelaskan operasi-operasinya.

\subsection{Metode Dempster Shafer}

Dalam sistem pakar terdapat banyak model dalam penalaran. tetapi banyak permaslahan yang tidak dapat terselesaiakan secara lengkap dan konsisten. Ketidakkonsistenan tersebut karena adanya penambahan fakta-fakta baru yang muncul, penalaran seperti itu disebut penalaran monotonis. untuk mengatasi masalah tersebut maka dapat menggunakan metode Dempster Shafer. Umumnya teori Dempster-Shafer. ditulis dalam suatu interval seperti pada Persamaan 1 dan Persamaan 2 [6].

1. Belief (Bel) adalah ukuran kekuatan evidence dalam mendukung suatu himpunan proposisi. Jika bernilai 0 maka mengindikasikan bahwa tidak ada evidence dan jika bernilai 1 menunjukkan adanya kepastian.

2. Plausibility (PI) dinotasikan sebagai persamaan $\mathrm{PI}(\mathrm{s})=1-\operatorname{Bel}(\ulcorner\mathrm{s})$

Plausibility juga bernilai 0 sampai 1 . Jika yakin akan $\ulcorner$ s, maka dapat dikatakan bahwa $\operatorname{Bel}(\ulcorner\mathrm{s})=$ 1 , dan $\operatorname{PI}(\mathrm{s})=0$.

Di dalammetode Dempster-Shafer dikenal adanya Frame of Discrement yang dinotasikan dengan $\theta$. Frame ini merupakan semesta pembicaraan dari sekumpulan hipotesis.

Tujuannya adalah untuk mengaitkan ukuran kepercayaan elemen-elemen $\theta$. Tidak semua evidence secara langsung mendukung tiap-tiap elemen. Sebagai contoh, panas mungkin hanya mendukung $\{\mathrm{F}, \mathrm{D}, \mathrm{B}\}$.

Untuk itu perlu adanya probabilitas fungsi densitas (m). Nilai $\mathrm{m}$ tidak hanya mendefinisikan elemen-elemen $\theta$ saja, namun juga semua subsetnya. Sehingga jika $\theta$ berisi n elemen, maka subset $\theta$ adalah $2^{\mathrm{n}}$. Kita harus menunjukkan bahwa jumlah semua $\mathrm{m}$ dalam subset $\theta$ sama dengan 1. Apabila tidak ada informasi apapun untuk memilih keempat hipotesis tersebut, maka nilai : $\mathrm{m}\{\theta\}=1,0$

Jika kemudian diketahui bahwa panas merupakan gejala dari flu, demam, bronchitis, dan Y

$$
\begin{aligned}
& m\{F, D, B\}=0, \\
& m\{\varnothing\}=1-0,8=0,2
\end{aligned}
$$
maka :

juga merupakan subset dari $\theta$ dengan $\mathrm{m}=0,8$

Apabila nilai diketahui $\mathrm{X}$ adalah subjekt dari $\theta$, dengan $\mathrm{m} 1$ sebagai fungsi densitasnya, dan $\mathrm{Y}$ juga merupakan subset dari $\theta$ dengan $\mathrm{m} 2$ sebagai fungsi densitasnya, maka dapat dibentuk fungsi kombinasi $\mathrm{m} 1$ dan $\mathrm{m} 2$ sebagai $\mathrm{m} 3$ sehingga didapatkan Persamaan 3.

$$
\begin{aligned}
& m i(Z) \frac{\sum X \cap Y=Z m 1(X) m 2(Y)}{1-\sum X \cap Y=\theta m 1(X) m 2(Y)} \text { P.2 } \\
& \text { Keterangan : } \\
& \mathrm{M} \quad=\text { Nilai } \\
& \text { Densitas(Kepercayaan) } \\
& \mathrm{XYZ}=\text { Himpunan Evidence } \\
& \Theta \quad=\text { Himpunan Kosong }
\end{aligned}
$$

\section{METODE PENELITIAN}

\subsection{Desain sistem}

Dalam desain sistem yang terdapat pada gambar dibawah hal yang harus dimiliki oleh user untuk mengakses sistem pakar adalah sebuah perangkat PC atau Smartphone tetnunya sudah memiliki akses internet, kemudian user mengunjungi laman sistem pakar dan langung masuk ke menu konsultasi penyakit anggur, user memilih gejala-gejala yang terdapat pada buah anggur, setelah selesai maka akan mucul kemungkinan penyakit yang menyerang buah anggur tersebut dan juga terdapat soslusi pengendalian penyakitnya

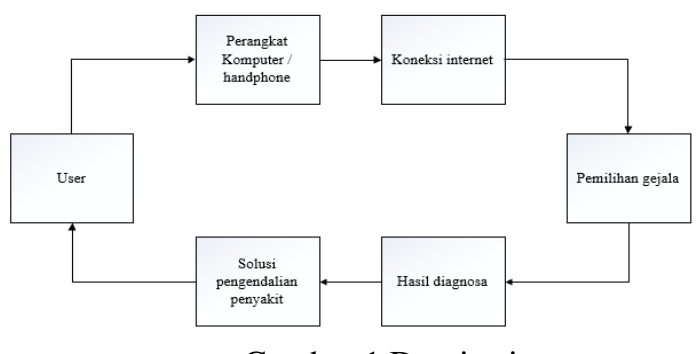

Gambar 1 Desain sistem

\subsection{Struktur Menu}

Dalam pembuatan struktur menu pada sistem pakar ini terdapat 4 menu yaitu Beranda, konsultasi, tentang anggur, dan login. Untuk menu pada halaman admin terdapat dashboard, penyakit, di dalam menu penyakit ini terdapat sub menu yaitu untuk edit, 
update dan delete data dari penyakit, pada menu gejala juga terdapat sub menu edit, update dan juga delete

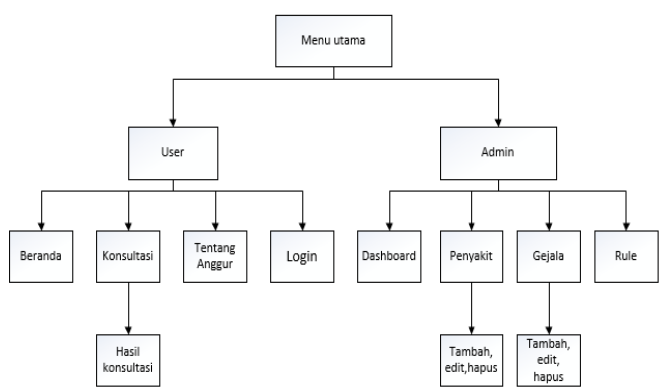

Gambar 2 Sturktur menu

\subsection{Flowchart Sistem}

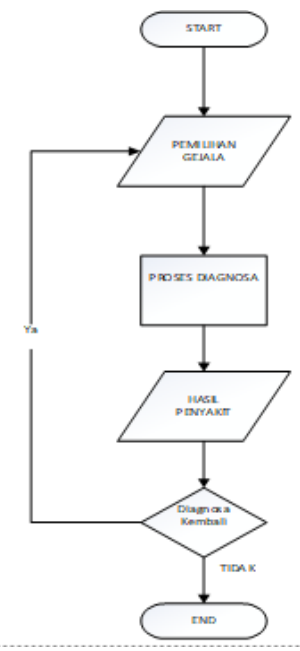

Gambar 3 Flowchart Sistem

\subsection{Mesin inferensi}

Dalam perancangan sistem pakar diagnosis penyakit buah anggur ini menggunakan metode penalaran Forward Chaining atau penalaran maju yang dimulai dari mengumpulkan fakta-fakta tentang suatu gejala dari penyakit yang yang diberikan oleh user sebagai masukan sistem, kemudian dilakukan pelacakan perhitungan sampai akhir berupa diagnosis kemungkinan penyakit yang diderita oleh oleh buah anggur dan beserta nilai kepercayaannya. Untuk proses penarikan kesimpulan dapat dilihat pada Gambar 4 yang merupakan gambaran pencarian solusi sistem pakar dengan menggunakan flowchart atau diagram alir.

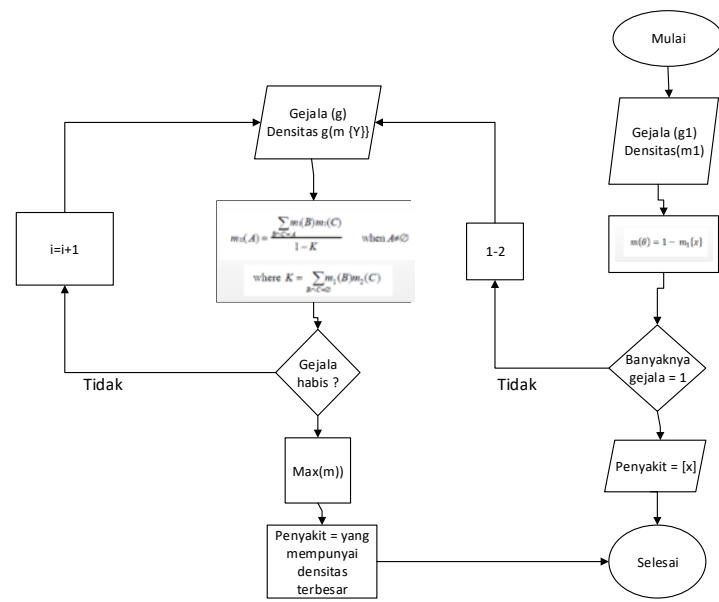

Gambar 4. Mesin Inferensi Dempster shafer

\subsection{Rule sistem pakar}

Berikut adalah tabel dari rule base sistem pakar penyakit buah anggur menggunakan metode dempster shafer berbasis web

\begin{tabular}{|c|c|c|c|c|c|c|c|c|c|c|c|c|c|c|}
\hline \multirow{2}{*}{$\begin{array}{l}\text { Kode } \\
\text { Gejala }\end{array}$} & \multirow{2}{*}{ Gejala } & \multicolumn{13}{|c|}{ Kode Penyakit } \\
\hline & & $\mathrm{P} 1$ & $\mathrm{P} 2$ & P3 & $\mathrm{P} 4$ & P5 & P6 & P7 & P8 & P9 & P10 & P11 & $\mathrm{P} 12$ & P13 \\
\hline G1 & $\begin{array}{l}\text { Bagian bawah daun berwarna } \\
\text { merah }\end{array}$ & $*$ & & & & & & & & & & & & \\
\hline G2 & Tepi daun membusuk & $*$ & & & & & & & & & & & & \\
\hline G3 & Tepi ranting membusuk & $*$ & & & & & & & & & & & & \\
\hline G4 & Daun mengering & $*$ & & & & & & & & & & & & \\
\hline G5 & $\begin{array}{l}\text { Buah yang masak menjadi } \\
\text { busuk }\end{array}$ & $*$ & & & & & & & & & & & & \\
\hline G6 & Buah menjadi lapuk & & $*$ & & & & & & & & & & & \\
\hline G7 & $\begin{array}{l}\text { Buah mengeluarkan bubuk } \\
\text { putih }\end{array}$ & & $*$ & & & & & & & & & & & \\
\hline G8 & $\begin{array}{l}\text { Permukaan atas dan daun } \\
\text { berbintik hijau dan } \\
\text { kekuningan }\end{array}$ & & & $*$ & & & & & & & & & & \\
\hline G9 & $\begin{array}{l}\text { Warna daun merah } \\
\text { kecoklatan }\end{array}$ & & & $*$ & & & & & & & & & & \\
\hline G10 & Bintik kecoklatan pada daun & & & $*$ & & & & & & & & $*$ & & \\
\hline
\end{tabular}




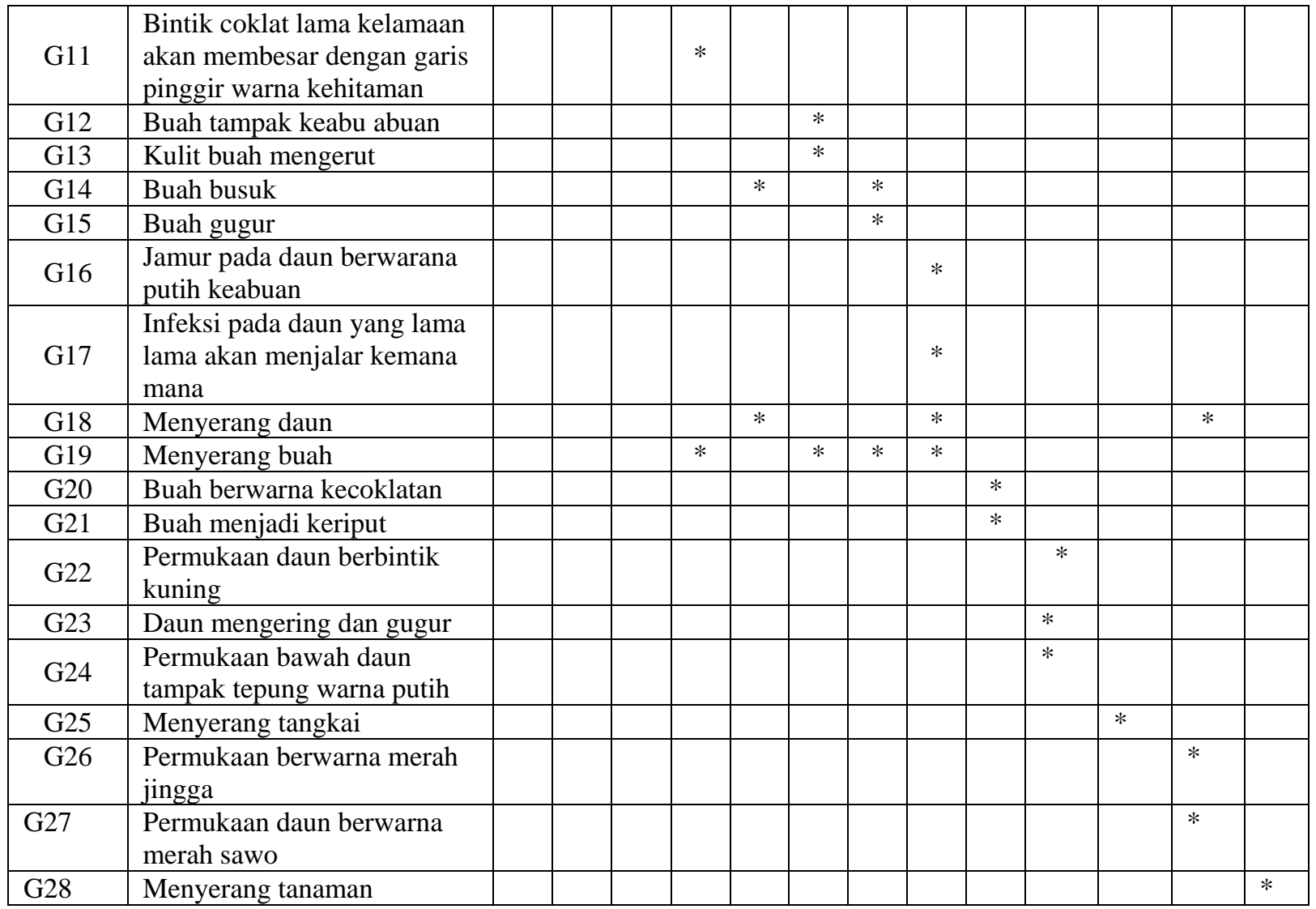

\section{HASIL DAN PEMBAHASAN}

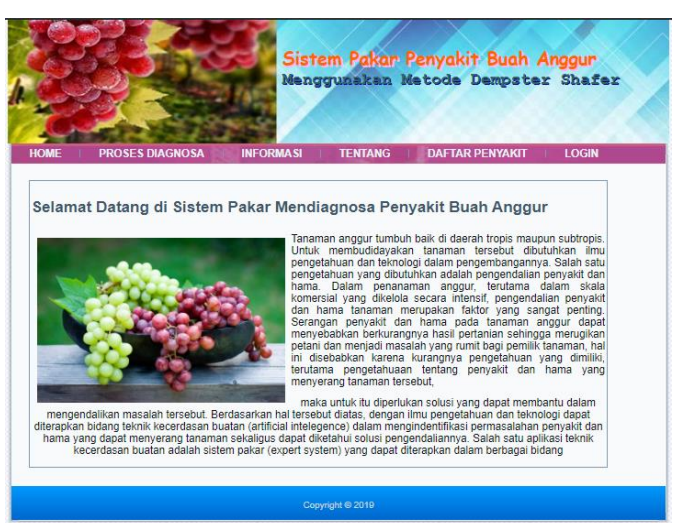

Gambar 5 tampilan home untuk user

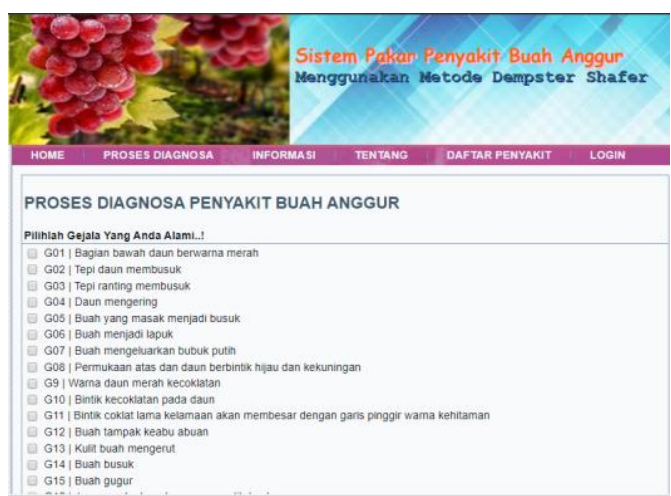

Gambar 6 tampilan menu diagnosa penyakit anggur

\subsection{Pengujian Fungsional Sistem}

Pengujian sistem merupakan proses menampilkan sistem dengan maksud untuk menemukan adanya kesalahan atau tidak pada sistem sebelum sistem dipublikasikan untuk digunakan oleh masyarakat. Hasil pengujian sistem ditunjuakkan pada Tabel 4.2 sebagai berikut.

Tabel 2

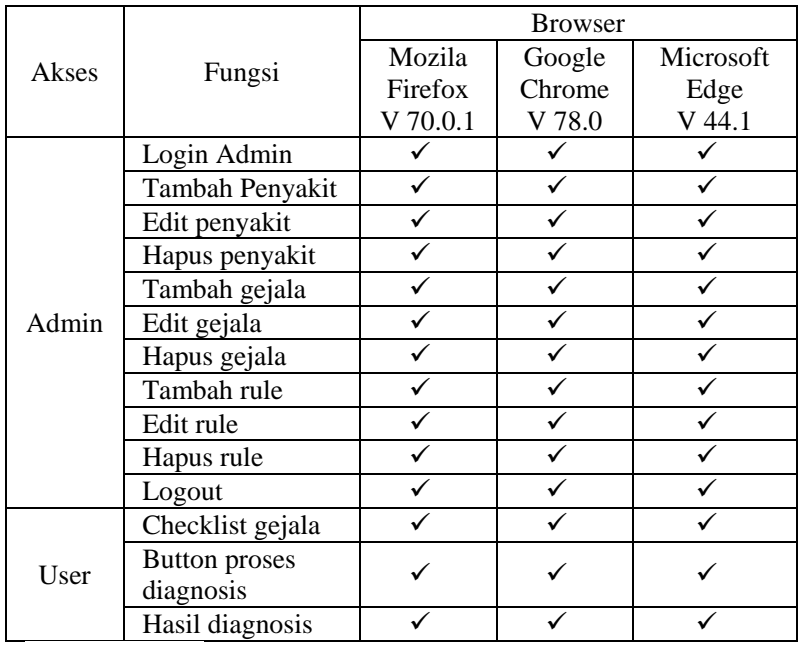

Keterangan :

$\checkmark=$ Berjalan.

$\boldsymbol{x}=$ Tidak Berjalan.

$\mathrm{V}=$ Versi Browser 


\subsection{Pengujian Kepuasan Terhadap Pengguna}

Pada pengujian kepuasan terhadap user, pengujian dilakukan secara langsung diantaranya oleh user, kuisioner tersebut disebar kepada 10 orang user untuk mengetahui seberapa besar kepuasan pengguna terhadap aplikasi Sistem Pakar Diagnosis Penyakit Angur . Hasil pengujian kepuasan pengguna ditunjukkan pada Tabel 3

Tabel 3

\begin{tabular}{|l|c|c|c|}
\hline \multirow{2}{*}{ Pertanyaan } & \multicolumn{3}{c|}{ Jawaban } \\
\cline { 2 - 4 } & $\begin{array}{c}\text { Sangat } \\
\text { Setuju }\end{array}$ & $\begin{array}{c}\text { Cukup } \\
\text { Setuju }\end{array}$ & $\begin{array}{c}\text { Tidak } \\
\text { Setuju }\end{array}$ \\
\hline $\begin{array}{l}\text { Apakah bahasa yang digunakan } \\
\text { pada tampilan website sistem } \\
\text { pakar mudah dipahami? }\end{array}$ & $\mathbf{3}$ & $\mathbf{3}$ & $\mathbf{1}$ \\
\hline $\begin{array}{l}\text { Apakah pemilihan gejala berupa } \\
\text { "check box' mudah digunakan? }\end{array}$ & $\mathbf{3}$ & $\mathbf{4}$ & - \\
\hline $\begin{array}{l}\text { Apakah sistem ini membantu } \\
\text { anda mengetahui penyakit pada } \\
\text { buah anggur sesuai dengan gejala } \\
\text { yang dipilih? }\end{array}$ & $\mathbf{4}$ & $\mathbf{3}$ & - \\
\hline $\begin{array}{l}\text { Apakah perpaduan warna } \\
\text { background dengan tulisan pada } \\
\text { sistem terlihat jelas? }\end{array}$ & $\mathbf{3}$ & $\mathbf{2}$ & $\mathbf{2}$ \\
\hline $\begin{array}{l}\text { Apakah perpaduan warna } \\
\text { background dengan semua } \\
\text { elemen halaman (tombol, menu, } \\
\text { ikon) sudah sesuai? }\end{array}$ & $\mathbf{3}$ & $\mathbf{4}$ & - \\
\hline Jumlah & $\mathbf{1 6}$ & $\mathbf{1 6}$ & $\mathbf{3}$ \\
\hline Persentase & $\mathbf{4 3 \%}$ & $\mathbf{4 3 \%}$ & $\mathbf{1 4 \%}$ \\
\hline
\end{tabular}

Pada pengujian kepuasan pengguna diambil hasil bahwa dari 7 petani yang telah diberi kuisioner memberikan nilai kepuasan dari segi penggunaan, tampilan antarmuka, manfaat, kelengkapan informasi aplikasi. Dari hasil pengujian didapatkan presentase sebanyak $43 \%$ menyatakan bahwa pengguna Sangat Setuju dan $43 \%$ menyatakan setuju dan 14\% menyatakan bahwa pengguna tidak setuju dengan sistem pakar diagnosis penyakit anggur.

\section{KESIMPULAN}

\subsection{Kesimpulan}

Berdasarkan hasil penelitian yang telah dilakukan, dapat ditarik kesimpulan bahwa:

1. Berdasarkan dari pengujian fungsionalitas sistem pakar diagnosis penyakit buah anggur berjalan sesuai dengan apa yang telah diharapkan.

2. Berdasarkan hasil dari pengujian pembangunan sistem pakar diagnosis penyakit buah anggur terdapat presentasi error sebesar $0,33 \%$
3. Pada pengujian kepuasan pengguna diambil hasil bahwa dari 7 petani yang telah diberi kuisioner memberikan nilai kepuasan dari segi penggunaan, tampilan antarmuka, manfaat, kelengkapan informasi aplikasi. Dari hasil pengujian didapatkan presentase sebanyak $43 \%$ menyatakan bahwa pengguna Sangat Setuju dan 43\% menyatakan setuju dan $14 \%$ menyatakan bahwa pengguna tidak setuju dengan sistem pakar diagnosis penyakakit buah anggur.

\subsection{Saran}

Beberapa saran untuk pengembangan lebih lanjut yang dapat diberikan setelah

dilakukannya penelitian ini adalah sebagai berikut:

1. Penambahan data penyakit anggur yang lebih lengkap.

2. Penyempurnaan desain user interface aplikasi.

3. Penyederhanaan bahasa pada gejala dan penyakit agar mudah dimengerti.

\section{DAFTAR PUSTAKA}

[1] Ihsan,Muhd, Agus,Fahrul,. Khairina, Marisa, Dyna ,2018. 'Penerapan Metode Dempster Shafer Untuk Sistem Deteksi Penyakit Tanaman Padi', Prosiding Seminar Ilmu Komputer dan Teknologi Informasi, Vol. 2, No. 1, Maret 2017

[2] Harry, Salistiwa.,2017. Rancang Bangun Sistem Pakar Diagnosa Penyakit Sapi Dengan Metode Depster Shafer Berbasis Web

[3] Sihotang, Tamando, Hengki.,2015. Sistem Pakar Untuk Mendiagnosisi Penyakit Pada Tanama Jagung Dengan Metode Bayes

[4] Wijayanti, Reni,. Winiarti, Sri 2013. Sistem Pakar Mendiagnosa Penyakit Pada Buahbuahan Pasca panen.

[5] Rahmat Adi Wicaksono, Dkk,.2018. Implementasi Metode Dempster-Shafer untuk Diagnosis Penyakit pada Tanaman Kedelai.

[6] Rahmat Adi Wicaksono, Dkk,.2018. Implementasi Metode Dempster-Shafer untuk Diagnosis Penyakit pada Tanaman Kedelai

[7] Sri Kusumadewi, 2003,. Penerapan Metode Dempster Shafer Untuk Mendiagnosa Penyakit Dari Akibat Bakteri Salmonella 